Endocrinol. Japon. 1986, 33 (5), 605-615

\title{
Pharmacokinetics of Methimazole in Normal Subjects and Hyperthyroid Patients
}

\author{
YukARI OKAMURA, ChIAKI SHIGEMASA AND TOHORU TATSUHARA*
}

\author{
The First Department of Internal Medicine and Department of \\ Hospital Pharmacy*, Tottori University School of Medicine, \\ 36-1 Nishi-machi, Yonago 683
}

\begin{abstract}
Serum and urinary concentrations of methimazole (MMI) were measured by high-performance liquid chromatography (HPLC) with an electrochemical detector (ECD) in 10 normal subjects and 43 hyperthyroid patients after intravenous and oral administration of the drug.

The pharmacokinetic parameters of MMI were estimated in 5 normal subjects and 15 hyperthyroid patients according to a two-compartment model after intravenous injection of a $10 \mathrm{mg}$ dose. The mean half-life of the distribution phase $\left(\mathrm{T}_{1 / 2} \alpha\right)$ was $2.7 \pm 1.0 \mathrm{~h}($ mean $\pm \mathrm{SD})$ and $3.1 \pm 1.4 \mathrm{~h}$ and that of the slower-phase $\left(T_{1 / 2} \beta\right)$ was $20.7 \pm 9.6 \mathrm{~h}$ and $18.5 \pm 12.9 \mathrm{~h}$ in normal subjects and hyperthyroid patients, respectively. There were no significant differences between pharmacokinetic parameters of normal subjects and those of hyperthyroid patients. No correlations between free $\mathrm{T}_{4}$ index $\left(\mathrm{FT}_{4} \mathrm{I}\right)$ and pharmacokinetic parameters were observed.

Maximum serum MMI concentrations $\left(\mathrm{C}_{\max }\right)(213 \pm 84$ and $299 \pm 92 \mathrm{ng} / \mathrm{ml})$ were attained $1.8 \pm 1.4 \mathrm{~h}$ and $2.3 \pm 0.8 \mathrm{~h}$ after a single dose of $10 \mathrm{mg}$ in 5 normal subjects and in 15 hyperthyroid patients, respectively. In hyperthyroid patients the time taken to reach the peak concentration $\left(\mathrm{T}_{\max }\right)$ after a single dose of $10 \mathrm{mg}$ was similar to that after a single $15 \mathrm{mg}$ and $30 \mathrm{mg}$ dose. The pharmacokinetic parameters, except $\mathbf{C}_{\max }$ and the area under the curve (AUC), were not affected by the administered dose and those, except $C_{\max }$, were not affected by the thyroid function.

All urine was collected at intervals of $3 \mathrm{~h}$ for the first $12 \mathrm{~h}$ and then at $24 \mathrm{~h}$ and $48 \mathrm{~h}$ after intravenous and oral administration of MMI. In all subjects, MMI rapidly appeared in the urine and the rate of excretion was highest in the first $3 \mathrm{~h}$. The cumulative urinary excretion of MMI was $5.5-8.5 \%$ of administered doses in normal subjects and hyperthyroid patients.

These findings in the present study are compatible with the assumption that the extent of absorption of MMI is high, if not complete, and hyperthyroidism does not affect the kinetics of MMI, and that interindividual variation is observed in the time taken to reach the peak concentration after oral administration.
\end{abstract}

Methimazole (MMI : 1-methyl-2-mer- captoimidazole) has been used for treating

Received March 31, 1986 of hyperthyroidism since Stanley and Astwood in 1949. The action of MMI is 
known to interfere with the synthesis and release of thyroid hormone. Although MMI is the most potent antithyroid drug known to man, details of its pharmacokinetics are still unknown. Many methods, such as isotopic (Alexander et al., 1969; Crooks et al., 1973), colorimetric (Pittmann et al., 1971; Vesell et al., 1975), and chromatographic (Skellern et al., 1974; Skellern et al., 1976; Skellern et al., 1980; Melander et al., 1980 ; Hallengren et al., 1982), have been reported for the determination of MMI in plasma and other biological fluids. These conventional methods may not be appropriate to monitor the therapeutic plasma levels after administration of the usual maintenance dose of MMI, because they are not specific and/or sensitive. We have developed a more specific and sensitive method, using high-performance liquid chromatography (HPLC) employing electrochemical detection for quantification of MMI in human serum without extraction procedure and in human urine with an Extrelut column.

This study was undertaken to elucidate the pharmacokinetics of MMI in normal subjects and untreated Graves' hyperthyroid patients receiving MMI orally and intravenously.

\section{Subjects and Methods}

\section{Subjects}

Ten normal adult male volunteers consented to be studied and forty-three patients with hyperthyroidism due to Grave's disease were studied. All patients had normal renal and liver function. The diagnosis of hyperthyroidism was based on elevation of serum thyroid hormone concentrations and thyroid ${ }^{123}$ I-uptake, and on complete suppression of serum TSH. The patients were not receiving any medication.

The subjects were divided into the following 6 groups: 1) group 1: five normal subjects (five men; aged 21-26yr); 2) group 2: fifteen patients (thirteen women and two men; aged 15-59 yr) ; 3) gloup 3 : five normal subjects (five men ; aged 25-35 yr); 4) group 4: fifteen patients (fourteen women and one man; aged 13-74 yr); 5) group 5: seven patients (four women and three men; aged $31-62 \mathrm{yr}$ ) ; 6) group 6: six patients (five women and one man; aged 15-59 yr). Details of subjects are shown in Table 1.

\section{Methods}

MMI was administered as follows $1 \mathrm{~h}$ after a light breakfast: intravenously $10 \mathrm{mg}$ to groups 1 and 2 ; orally $10 \mathrm{mg}$ to groups 3 and 4 ; orally $15 \mathrm{mg}$ to group 5 ; and orally $30 \mathrm{mg}$ to group 6. An initial blood sample was taken as a control, and then ten to twelve blood samples were taken at varying time intervals between $30 \mathrm{~min}$ and $48 \mathrm{~h}$ after administration of MMI. All blood samples were immediately centrifuged and then stored at $-20^{\circ} \mathrm{C}$. All urine was collected at intervals of $3 \mathrm{~h}$ for the first $12 \mathrm{~h}$ then at $24 \mathrm{~h}$ after drug administration. Furthermore, urine was collected for a second $24 \mathrm{~h}$ period in groups $2,4,5$, and 6 . Urine samples were stored at $-20^{\circ} \mathrm{C}$ until analysis.

\section{Measurement of MMI}

Serum concentration of MMI was determined by the HPLC system (Waters Assoc., Model

Table 1. Subjects

\begin{tabular}{|c|c|c|c|c|c|c|c|c|}
\hline & & $\begin{array}{l}\text { No. of } \\
\text { cases }\end{array}$ & $\begin{array}{l}\text { Dose } \\
\text { (mg) }\end{array}$ & Route & $\begin{array}{c}\text { Age } \\
\text { (years) }\end{array}$ & $\begin{array}{c}\text { Weight } \\
\text { (kg) }\end{array}$ & $\begin{array}{c}\mathrm{T}_{3} \\
(\mathrm{ng} / \mathrm{dl})\end{array}$ & $\mathrm{FT}_{4} \mathrm{I}$ \\
\hline Group 1 & Normal subjects & 5 & 10 & IV & $23.2 \pm 1.7$ & $61.8 \pm 4.5$ & $138.4 \pm$ & $3.1 \pm 0.3$ \\
\hline Group 2 & Graves' patients & s 15 & 10 & IV & $37.7 \pm 15.4$ & $49.2 \pm 6.2$ & $489.8 \pm 148.5$ & $11.3 \pm 3.2$ \\
\hline Group 3 & Normal subjects & ts 5 & 10 & Oral & $28.6 \pm 3.8$ & $58.0 \pm 3.6$ & $144.5 \pm 6.8$ & $3.4 \pm 0.4$ \\
\hline Group 4 & Graves' patients & s 15 & 10 & Oral & $49.7 \pm 15.8$ & $46.8 \pm 4.4$ & $385.5 \pm 116.4$ & $9.8 \pm 2.4$ \\
\hline Group 5 & Graves' patients & s 7 & 15 & Oral & $44.9 \pm 10.5$ & $51.6 \pm 7.8$ & $401.3 \pm 152.9$ & $1.9 \pm 2.4$ \\
\hline Group 6 & Graves' patients & 6 & 30 & Oral & $28.5 \pm 15.0$ & $54.8 \pm 11.3$ & $387.2 \pm 181.6$ & $8.4 \pm 2.1$ \\
\hline
\end{tabular}


M-6000) with an electrochemical detector (Bioanalytical Systems). This method was capable of detecting $10 \mathrm{ng} / \mathrm{ml}$ of MMI and not affected by the metabolites of the drug (Tatsuhara et al., 1985).

Similarly, the concentration of MMI in urine was determined using the same chromatographic system as for the following procedure. Urine was diluted with the same volume of water, and this mixture was transfered directly onto an Extrelut column. After $15 \mathrm{~min}$, the sample was elutriated with chloroform. The solvent was evaporated off on a dry-block at $60^{\circ} \mathrm{C}$, and the residue was redissolved in $1 \mathrm{ml}$ of methanol containing the internal standard, and then $10 \mu \mathrm{l}$ was injected onto the HPLC column. This procedure will be described in detail elsewhere (Tatsuhara, in preparation).

\section{Pharmacokinetic Analysis}

Serum concentrations following intravenous administration were curve-fitted as follows:

$$
\mathrm{C}_{\mathrm{t}}=\mathrm{Ae}^{-\alpha \mathrm{t}}+\mathrm{Be}^{-\beta \mathrm{t}}
$$

where $C_{t}$ is the serum concentration of MMI at time $\mathrm{t} ; \mathrm{A}$ and $\mathrm{B}$ are coefficient rates; $\alpha$ is the initial disposition rate constant and $\beta$ is the terminal rate constant.

The rates constant of for drug transfer between compartments 1 and 2 , the blood and tissues, are represented by $\mathrm{k}_{12}$ and $\mathrm{k}_{21}$, and $\mathrm{k}_{\mathrm{e}}$ is the rate constant for elimination of drug from the blood.

The volumes of distribution in the postdistributive phase $\left(\mathrm{Vd}_{\mathrm{area}}\right)$ and $\mathrm{k}_{12}, \mathrm{k}_{21}, \mathrm{k}_{\mathrm{e}}$ were calculated as followed:

$$
\begin{aligned}
\mathrm{Vd}_{\text {area }} & =\text { Dose } /(\mathrm{AUC} \cdot \beta) \\
\mathrm{k}_{21} & =(\mathrm{A} \beta+\mathrm{B} \alpha) /(\mathrm{A}+\mathrm{B}) \\
\mathrm{k}_{\mathrm{e}} & =\alpha \beta / \mathrm{k}_{21} \\
\mathrm{k}_{12} & =\alpha+\beta-\mathrm{k}_{\mathrm{e}}-\mathrm{k}_{21}
\end{aligned}
$$

The maximum serum concentration $\left(\mathrm{C}_{\max }\right)$ and the time $\left(\mathrm{T}_{\max }\right)$ of its occurrence following oral administrations were read directly from the observed serum concentration-time data. The area under the serum concentration-time curve from time zero to infinity was calculated as follows :

$$
\mathrm{AUC}=\mathrm{AUC}_{0-\mathrm{t}}+\mathrm{C}_{\mathrm{t}} / \beta
$$

where $\mathrm{AUC}_{0-\mathrm{t}}$ is the area calculated by trapezoidal summation from time zero to the time $t$ of the last measurable serum concentration, $\mathrm{C}_{\mathrm{t}}$.

The clearance was calculated by a modelindependent method as follows:

$$
\mathrm{Cl}=\text { Dose } / \mathrm{AUC}
$$

\section{Materials}

MMI powder was kindly provided by Chugai Pharmaceutical Co. (Tokyo, Japan). At the Department of Hospital Pharmacy of Tottori University School of Medicine, $10 \mathrm{mg}$ of MMI powder was throughly dissolved in $1 \mathrm{ml}$ of physiological salt solution, enclosed in an ampoule and sterilized by autoclaving. The tablets af MMI (Mercazole ${ }^{\circledR}$ ) were obtained from Chugai Pharmaceutical Co. (Tokyo ,Japan).

\section{Measurement of serum thyroid hormone concen- trations}

The serum concentrations of $T_{4}$ nd $T_{3}$ were determined by radioimmunoassay using the commercial kits $\left(\mathrm{T}_{4}\right.$ : Thyrotest RIA-4, NuclearMedical Laboratories, Irving, Texas; $\mathrm{T}_{3}: \mathrm{T}-3$ RIABEAD, Dainabot Radioisotope Lab., Tokyo, Japan). $T_{3}$ uptake was measured with a commercial kit (Thyrotest-3, Nuclear-Medical Laboratories, Irving, Texas). Free $\mathrm{T}_{4}$ index $\left(\mathrm{FT}_{4} \mathrm{I}\right)$ was calculated with the following formula: $T_{4} \times$ $\mathrm{T}_{3}$ uptake $\times 1 / 100$.

In our clinic, normal ranges for serum $\mathrm{T}_{4}$ and $\mathrm{T}_{3}$ concentrations, $\mathrm{T}_{3}$ uptake value, and $\mathrm{FT}_{4} \mathrm{I}$ are $4.5-12.5 \mu \mathrm{g} / \mathrm{dl}, \quad 90-210 \mathrm{ng} / \mathrm{dl}, 34-44 \%$, and $1.9-4.2$, respectively.

\section{Statistical analysis}

All values were expressed as the mean $\pm S D$. The statistical significance of difference was analysed by Student's paired and unpaired $t$ test.

\section{Results}

The serum concentration-time curves after a single intravenous administration of $10 \mathrm{mg}$ MMI in normal subjects and hyperthyroid patients are shown in Fig. 1. The results obtained from the intravenous injection of MMI demonstrated in a semilogarithmic plot a two-compartment curve composed of a short rapid distribution phase ( $\alpha$-phase) followed by a linear, and slow decrease in the serum concentration values ( $\beta$-phase) (Fig. 2). The pharmacokinetic parameters in groups $1-6$ were 

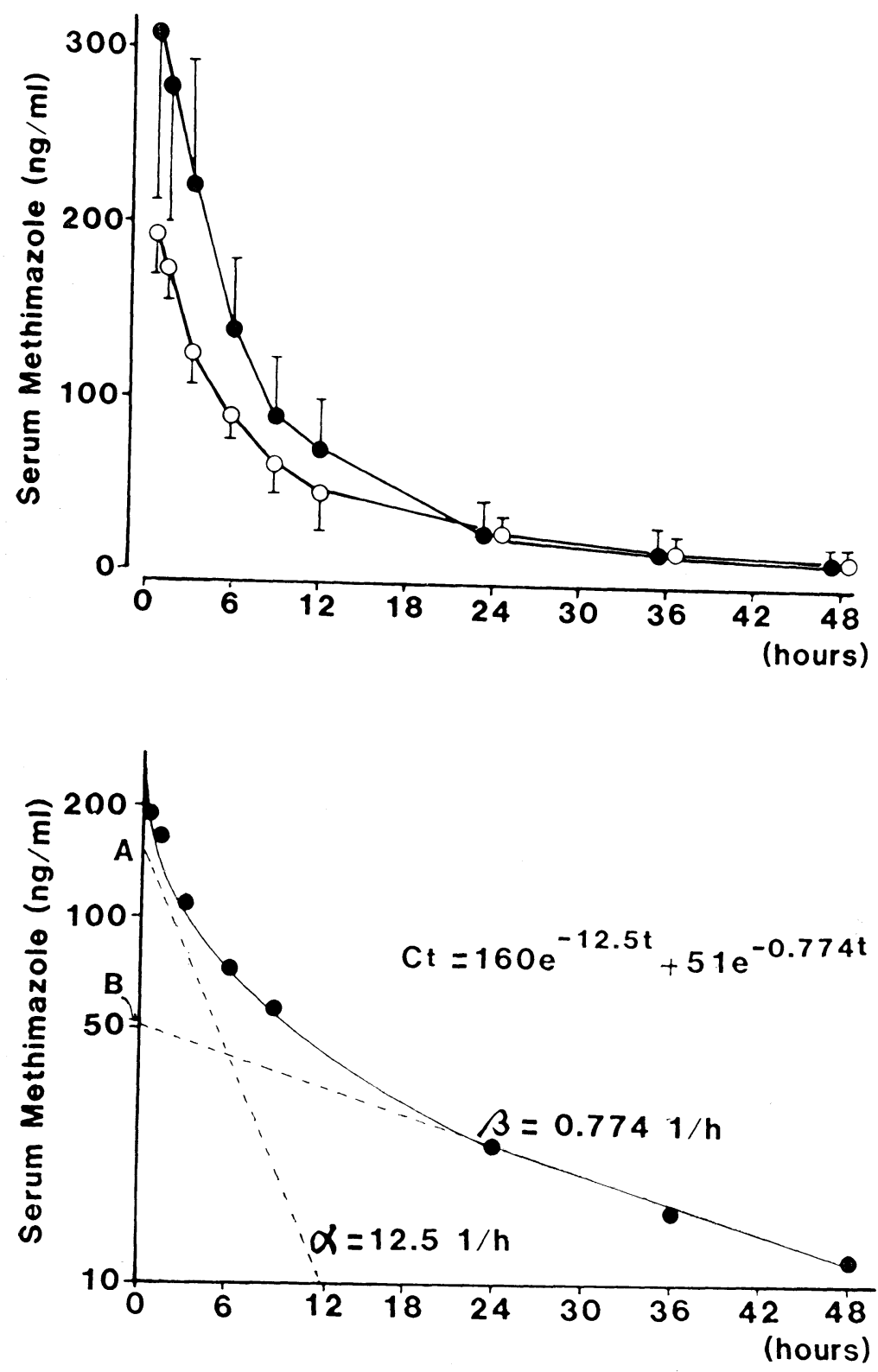

Fig. 1. Mean ( \pm SD) concentration-time profiles of MMI in 5 normal subjects $(\bigcirc)$ and 15 hyperthyroid patients (O) following intravenous administration of $10 \mathrm{mg}$ dose
Fig. 2. Elimination curve of MMI in serum of a normal subject after intravenous administration of $10 \mathrm{mg}$ dose calculated with a two-compartment model. Table 2 shows the pharmacokinetic parameters after intravenous administration of $10 \mathrm{mg}$ MMI. The mean half-life of the distribution $\left(\mathrm{T}_{1 / 2} \alpha\right)$ in normal subjects and hyperthyroid patients was $2.7 \pm 1.0 \mathrm{~h}$ and $3.1 \pm 1.4 \mathrm{~h}(\mathrm{P}=\mathrm{NS})$, and the mean half-life of the elimination for the slower-phase $\left(\mathrm{T}_{1 / 2} \beta\right)$ was $20.7 \pm 9.6 \mathrm{~h}$ and $18.5 \pm 12.9 \mathrm{~h}$ $(\mathrm{P}=\mathrm{NS})$, respectively. Other pharmacokinetic parameters, $\mathrm{Vd}_{\text {area }}, \mathrm{AUC}, \mathrm{K}_{12}, \mathrm{~K}_{21}$, $\mathrm{K}_{\mathrm{e}}$, and $\mathrm{Cl}$, in normal subjects were not significantly different from those in hyperthyroid patients. There is no significant 
Table 2. The pharmacokinetic parameters of MMI in normal subjects and hyperthyroid patients after intravenous administration of the drug

\begin{tabular}{|c|c|c|c|c|c|c|c|c|c|}
\hline & $\begin{array}{c}\text { Dose } \\
(\mathrm{mg} / \mathrm{kg})\end{array}$ & $\begin{array}{c}\mathrm{T}_{1 / 2} \alpha \\
(\mathrm{h})\end{array}$ & $\begin{array}{c}\mathrm{T}_{1 / 2} \beta \\
\text { (h) }\end{array}$ & $\begin{array}{l}\mathrm{k}_{12} \\
(1 / \mathrm{h})\end{array}$ & $\begin{array}{c}\mathrm{k}_{21} \\
(1 / \mathrm{h})\end{array}$ & $\begin{array}{c}k_{\mathrm{e}} \\
(1 / \mathrm{h})\end{array}$ & $\begin{array}{l}\mathrm{V}_{\mathrm{d} \text { area }} \\
(\mathrm{L} / \mathrm{kg})\end{array}$ & $\underset{(\mathrm{ng} \cdot \mathrm{h} / \mathrm{ml})}{\mathrm{AUC}}$ & $\underset{(\mathrm{ml} / \mathrm{kg} / \mathrm{min})}{\mathrm{Cl}}$ \\
\hline Group 1 & $\begin{array}{l}0.16 \\
\pm 0.02\end{array}$ & $\begin{array}{l}2.7 \\
\pm 1.0\end{array}$ & $\begin{array}{r}20.7 \\
\pm 9.6\end{array}$ & $\begin{array}{l}0.10 \\
\quad \pm 0.04\end{array}$ & $\begin{array}{l}0.11 \\
\quad \pm 0.08\end{array}$ & $\begin{array}{l}0.09 \\
\quad \pm 0.02\end{array}$ & $\begin{array}{l}2.1 \\
\pm 0.6\end{array}$ & $\begin{array}{l}2450 \\
\pm 836\end{array}$ & $\begin{array}{l}1.2 \\
\pm 0.3\end{array}$ \\
\hline Group 2 & $\begin{array}{l}0.21^{*} \\
\quad \pm 0.02\end{array}$ & $\begin{array}{l}3.1 \\
\pm 1.4\end{array}$ & $\begin{array}{l}18.5 \\
\pm 12.9\end{array}$ & $\begin{array}{l}0.07 \\
\quad \pm 0.05\end{array}$ & $\begin{array}{l}0.10 \\
\quad \pm 0.07\end{array}$ & $\begin{array}{l}0.13 \\
\quad \pm 0.03\end{array}$ & $\begin{array}{l}1.9 \\
\pm 1.1\end{array}$ & $\begin{array}{l}2922 \\
\quad \pm 915\end{array}$ & $\begin{array}{l}1.2 \\
\pm 0.3\end{array}$ \\
\hline
\end{tabular}

Table 3. Correlation between each of the pharmacokinetic parameters after intravenous administration of $10 \mathrm{mg}$ MMI and thyroid function in hyperthyroid patients

\begin{tabular}{lcccccccc}
\hline & $\mathrm{T}_{1 / 2} \alpha$ & $\mathrm{T}_{1 / 2} \beta$ & $\mathrm{k}_{12}$ & $\mathrm{k}_{21}$ & $\mathrm{ke}$ & $\mathrm{Vd}_{\text {area }}$ & $\mathrm{AUC}$ & $\mathrm{Cl}$ \\
\hline $\mathrm{FT}_{4} \mathrm{I}$ & 0.01 & -0.08 & -0.16 & -0.13 & 0.44 & -0.20 & 0.44 & -0.13 \\
$\mathrm{~T}_{3}$ & 0.08 & -0.13 & -0.11 & -0.06 & 0.40 & -0.21 & 0.25 & -0.01 \\
\hline
\end{tabular}

Values are correlation coefficients. $(\mathrm{N}=15)$

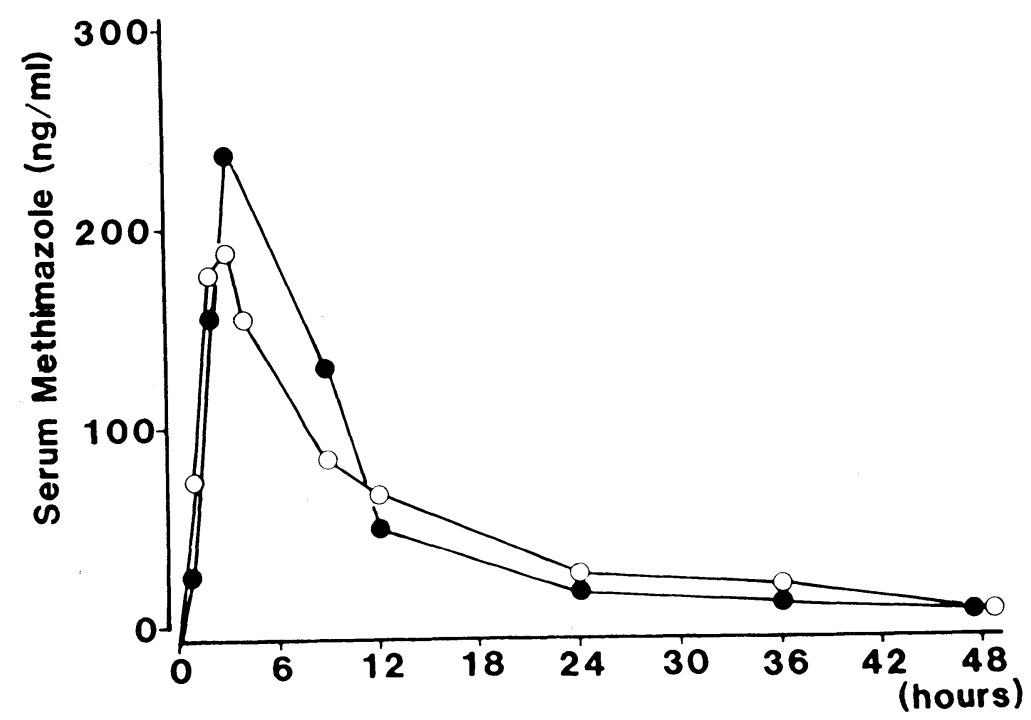

Fig. 3. Serum concentration-time profiles of MMI in a normal subject $(\bigcirc)$ and a hyperthyroid patient $(\bullet)$ following oral administration of a single 10 $\mathrm{mg}$ dose

difference between $\mathrm{K}_{12}$ and $\mathrm{K}_{21}$ in both normal subjects and hyperthyroid patients.

No significant correlation between each of the pharmacockinetic parameters and their thyroid hormone levels (Table 3) or ages was observed in hyperthyroid patients.

In hyperthyriod patients the serum concentration of MMI $30 \mathrm{~min}$ after intravenous administration was higher than that of normal subjects.

Serum concentration-time curves after oral administration of $10 \mathrm{mg}$ MMI in a normal subject and a hyperthyroid patient are shown in Fig. 3, where the combined curves of distribution ( $\alpha$-phase) and elimination ( $\beta$ phase) were observed as well as after 


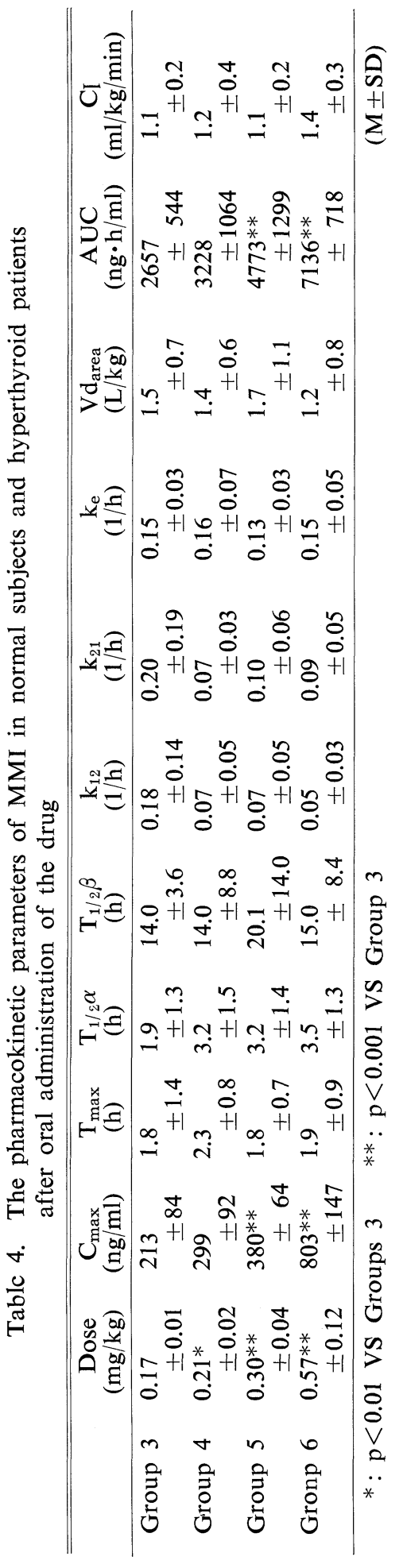

intravenous administration. As shown in Table $4, \mathrm{C}_{\max }(213 \pm 84 \mathrm{ng} / \mathrm{ml})$ was recorded at $1.8 \pm 1.4 \mathrm{~h}$ after oral administration of $10 \mathrm{mg}$ MMI in normal subjects. $T_{\max }$ varied from 0.5 to $4 \mathrm{~h}$ in normal subjects. $\mathrm{C}_{\max }$ $(299 \pm 92 \mathrm{ng} / \mathrm{ml}, 380 \pm 64 \mathrm{ng} / \mathrm{ml}$, and $803 \pm$ $147 \mathrm{ng} / \mathrm{ml}$ ) were recorded at $2.3 \pm 0.8 \mathrm{~h}, 1.8$ $\pm 0.7 \mathrm{~h}$, and $1.9 \pm 0.9 \mathrm{~h}$ after 10,15 , and $30 \mathrm{mg}$ doses, respectively. In hyperthyroid patients $\mathrm{C}_{\max }$ after oral dosing were slightly higher than those of normal subjects, but not significantly, and $T_{\max }$ were similar to those in normal subjects. $\mathrm{C}_{\max }$ and AUC were significantly affected by the administered dose. In other pharmacokinetic parameters after oral administration, no significant differences were observed between normal subjects and hyperthyroid patients.

MMI rapidly appeared in the urine in all groups. As shown in Fig. 4, the rate of excretion was highest in the first $3 \mathrm{~h}$, and the values averaged $68 \pm 43 \mu \mathrm{g} / \mathrm{h}$ and $116 \pm 83 \mu \mathrm{g} / \mathrm{h}$ after intravenous administration and $84 \pm 41 \mu \mathrm{g} / \mathrm{h}$ and $72 \pm 38 \mu \mathrm{g} / \mathrm{h}$ after oral administration in normal subjects and hyperthyroid patients, respectively. Cumulative urinary excretion (see Table 5) after intravenous and oral administration of $10 \mathrm{mg}$ MMI in normal subjects was $5.5 \pm 0.8 \%$ and $7.2 \pm 1.0 \%$ of the administered dose in $24 \mathrm{~h}$. In hyperthyroid patients, that after intravenous administration of $10 \mathrm{mg}$ MMI reached $8.0 \pm 3.9 \%$, and oral doses of 10,15 and $30 \mathrm{mg}$ were $7.3 \pm 2.4 \%, 8.0 \pm 3.0 \%$, and 5.6 $\pm 1.3 \%$, respectively. In the urine samples collected during the second 24-hour period following drug administration in hyperthyroid patients, unchanged MMI was detectable in 8 out of 12 cases ( $10 \mathrm{mg}$ intravenously), 10 out of 14 cases ( $10 \mathrm{mg}$ orally), 6 out of 7 cases ( $15 \mathrm{mg}$ orally), and 5 out of 6 cases (30 mg orally), but was only $0.5-0.8 \%$ of the administered dose. 


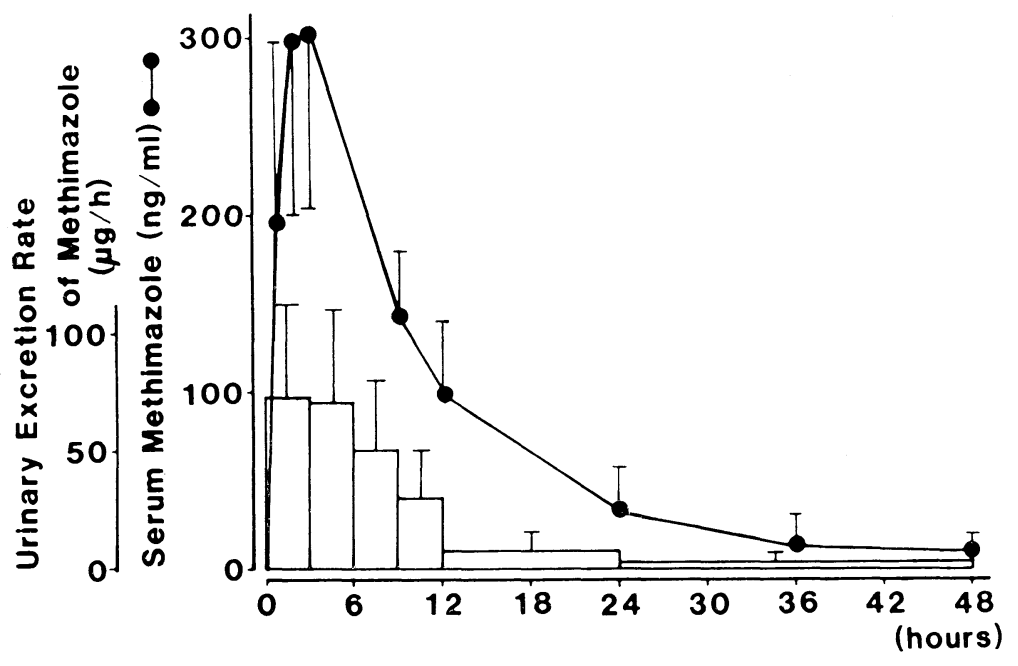

Fig. 4. Serum concentration (O) and urinary excretion rate (calumn) of MMI in 15 hyperthyroid patients following oral administration of a single $10 \mathrm{mg}$ dose

Table 5. Cumulative urinary excretion of MMI

\begin{tabular}{|c|c|c|c|c|c|c|}
\hline & $3 \mathrm{~h}$ & $6 \mathrm{~h}$ & $9 \mathrm{~h}$ & $12 \mathrm{~h}$ & $24 \mathrm{~h}$ & $48 \mathrm{~h}$ \\
\hline Group 1 & $2.1 \pm 1.3$ & $3.1 \pm 1.7$ & $4.0 \pm 0.6$ & $4.0 \pm 0.6$ & $5.5 \pm 0.8$ & \\
\hline Group 2 & $3.5 \pm 2.5$ & $5.7 \pm 3.7$ & $6.5 \pm 2.2$ & $6.8 \pm 3.6$ & $8.0 \pm 4.0$ & $8.5 \pm 4.0$ \\
\hline Group 3 & $2.5 \pm 1.2$ & $4.0 \pm 1.3$ & $5.1 \pm 1.5$ & $5.9 \pm 1.5$ & $7.2 \pm 1.0$ & \\
\hline Group 4 & $2.2 \pm 1.2$ & $4.1 \pm 1.6$ & $5.7 \pm 2.3$ & $6.6 \pm 2.2$ & $7.3 \pm 2.4$ & $7.9 \pm 2.5$ \\
\hline Group 5 & $2.1 \pm 1.4$ & $4.0 \pm 2.3$ & $5.4 \pm 2.9$ & $6.6 \pm 3.0$ & $8.0 \pm 3.0$ & $8.8 \pm 3.1$ \\
\hline Group 6 & $1.3 \pm 0.9$ & $2.3 \pm 1.2$ & $3.5 \pm 1.1$ & $4.7 \pm 1.1$ & $5.6 \pm 1.3$ & $6.2 \pm 1.4$ \\
\hline
\end{tabular}

\section{Discussion}

Pharmacokinetic parameters of MMI have been described in several papers. Pittman et al. (1971) and Vesell et al. (1975) colorimetrically determined the plasma concentration of MMI after oral administration. In their studies, half-lives of MMI were $6.4 \mathrm{~h}$ (Pittman et al., 1971) and 9.3 $\pm 1.4 \mathrm{~h}(\mathrm{M} \pm$ SEM) (Vesell et al., 1975) in normal subjects and $6.9 \pm 0.6 \mathrm{~h}(\mathrm{M} \pm \mathrm{SEM})$ in hyperthyroid patients. Using the HPLC method, the half-lives of MMI in serum were found to be $2.25-9.5 \mathrm{~h}$ (Melander et al., 1980) in normal subjects and $2.96 \pm 0.34 \mathrm{~h}(\mathrm{M} \pm \mathrm{SEM})$ (Skellern et al., 1980) and 2.9-7.1 h (Hallengren et al., 1982) in hyperthyroid patients.
In these studies, the authors applied onecompartment models to the serum concentration curve of MMI after oral administration of the drug. A two-compartment model was proposed by Balzer et al., (1975) for ${ }^{14} \mathrm{C}$-MMI after intravenous injection in humans; $\mathrm{T}_{1 / 2} \alpha$ was $35 \mathrm{~min}$ and $\mathrm{T}_{1 / 2} \beta$ was $28 \mathrm{~h}$. These data derived from radioactivity measurements may overestimate the concentration of the active drug.

In the present study, MMI in serum was determined by the specific and sensitive HPLC method, as described by Tatsuhara et al. (1985). In normal subjects and hyperthyroid patients, the HPLC method was able to detect MMI two days after intravenous and oral administration of $10 \mathrm{mg}$ MMI. As shown in Figs. 1, 2, and 3, the 
serum concentration-time profiles of MMI could be described with a two-compartment model. $\mathrm{T}_{1 / 2} \alpha$ values after intravenous and oral administration obtained in the present study are similar to the half-lives after oral administration of previous reports (Skellern et al., 1980; Melander et al., 1980; Hallengren et al., 1982) using the HPLC method. In the present study, no significant differences were found between $T_{1 / 2} \alpha$ and $T_{1 / 2} \beta$ in normal subjects and those in hyperthyroid patients. According to the report of Cooper et al. (1984), the mean halflives of disappearance measured by RIA after oral administration of $30 \mathrm{mg}$ MMI in normal subjects and hyperthyroid patients were $6.0 \mathrm{~h}$ and $6.8 \mathrm{~h}$, which were longer than those obtained in the present study. Kampmann and Skovsted (1974; 1975) indicated that no significant differences existed between the kinetics of PTU according to a two-compartment model in normal subjects and those in hyperthyroid patients, and indicated no significant correlation between thyroid function and PTU kinetics.

Studies in patients with altered thyroid status are limited. Crooks et al. (1973) and Vesell et al. (1975) observed shorter halflives of MMI in hyperthyroid patients. On the other hand, Hallengren et al. (1982) reported that for the kinetic profiles of oral MMI, the elimination half-life and the AUC were not affected by hyperthyroid states. They used a specific HPLC assay which could distinguish metabolites of MMI after oral administration of MMI, and used a one-compartment model. Cooper et al. (1984) reported that the mean half-life of disappearance after a $60 \mathrm{mg}$ dose was similar in normal subjects and hyperthyroid patients using RIA and a one-compartment model. In the present study using a more sensitive HPLC assay, pharmacokinetic parameters of MMI were not shown to correlate with $\mathrm{T}_{3}$ and $\mathrm{FT}_{4} \mathrm{I}$, and no significant differences between pharmacokinetic parameters after intravenous administration of MMI to normal subjects and hyperthyroid patients were observed. This suggests that thyroid hormones do not depress the metabolism of MMI.

After oral administration of MMI to normal subjects, $\mathrm{T}_{\max }$ was $1 \mathrm{~h}$ (Pittman et al., 1971), 1-3 h (Melander, 1980), $2 \mathrm{~h}$ (Cooper et al., 1984), and 0.75-2.0 h (Hallengren et al., 1982). In the present study, $\mathrm{T}_{\max }$ varied from 0.5 to $4 \mathrm{~h}$ in normal subjects. In hyperthyroid patients, $T_{\max }$ was 0.5-1.5 h (Skellern et al., 1980), $1 \mathrm{~h}$ (Cooper et al 1984), and 0.25-3 h (Hallengren et al., 1982) after MMI administration. In the present study, $T_{\max }$ after administration of $10 \mathrm{mg}$ of MMI was similar in normal subjects and hyperthyroid patients. No correlation between $\mathrm{T}_{\max }$ and thyroid hormone levels was observed in hyperthyroid patients.

In previously published reports, the subjects were given $60 \mathrm{mg}$ MMI (Skellern et al., 1980; Melander et al., 1980; Cooper et al., 1984), 40 mg MMI (Hallengren et al., 1982), and $30 \mathrm{mg}$ MMI (Cooper et al., 1984) because of low sensitivity of the method used to measure MMI. We measured MMI after oral administration of the usual doses of 10,15 , and $30 \mathrm{mg}$ MMI. $\mathrm{C}_{\max }$ after $30 \mathrm{mg}$ MMI administration was $803 \pm 147$ $\mathrm{ng} / \mathrm{ml}$ and consistent with values using RIA (Cooper et al., 1984).

In normal subjects, Melander et al. (1980) and Cooper et al. (1984) reported that there were great interindividual variations in the $C_{\max }$. In the present study, smaller interindividual variations than those in previous reports were observed.

According to Shimmins et al. (1969), using total radioactivity of ${ }^{35} \mathrm{~S}-\mathrm{MMI}$, the bioavailability of MMI was 0.99 and 0.81 in two patients. The use of total radiolabel data may give no indication whether the drug was metabolized. Using a specific HPLC assay which could "distinguish metabolites of MMI, we found that the values for AUC after administration of $10 \mathrm{mg}$ 
dose orally were similar to those after administration intravenously to both normal subjects and hyperthyroid patients, though the subjects given MMI orally were not the same subjects as those given MMI intravenously. These data indicate that the extent of absorption of MMI is high, if not complete.

$\mathrm{C}_{\max }$ after oral administration and serum concentration of MMI 30 min after intravenous administration was about $40 \%$ and $50 \%$ higher in hyperthyroid patients reflecting the reduction in total body weight. After oral administration, a significant correlation between the dose $(\mathrm{mg} / \mathrm{kg})$ and $\mathrm{C}_{\max }$ was observed in normal subjects and hyperthyroid patients.

Balzer et al. (1979) reported that within $48 \mathrm{~h}, 87 \%$ and $80 \%$ of the administered activity of ${ }^{14} \mathrm{C}$-MMI appeared in urine in normal subjects and hyperthyroid patients, respectively. In another report (Marchant, 1979), $65 \%$ of the administered activity of ${ }^{35} \mathrm{~S}-\mathrm{MMI}$ was recovered in urine within $48 \mathrm{~h}$ in hyperthyroid patients. Using colorimetric and chromatographic methods, the amount of unchanged MMI excreted in the urine of euthyroid and hyperthyroid patients was only 7\% (24 h) (Marchant, 1979) and $12 \%(48 \mathrm{~h})$ (Pittman et al., 1971) of the administered dose. Using a specific HPLC method, which could detect $10 \mathrm{ng} \mathrm{MMI} / \mathrm{ml}$ in urine and not interfere with the metabolites of the drug, the cumulative urinary extent of excretion after intravenous and oral administration of a $10 \mathrm{mg}$ dose of MMI in normal subjects was not significantly different from those in hyperthyroid patients. Cumulative urinary excretions $(5.5-8.0 \%)$ in the present study were similar to those in two pervious reports (Marchant, 1979; Pittman et al., 1971). About 21\% of administered ${ }^{35}$ S-MMI (Papapetrou et al., 1972) and $10 \%$ of administered ${ }^{14} \mathrm{C}$-MMI (Sitar and Thonhill, 1973) were found in rat bile. On the other hand, only $1.5 \pm 0.2 \% \quad(\mathrm{M} \pm$ SEM) of administered ${ }^{14} \mathrm{C}$-MMI (Sitar and
Thornhill, 1973) and 3.6\% of administered ${ }^{35}$ S-MMI (Marchant and Alexander, 1972) were recovered in 48 and $24 \mathrm{~h}$ rat fecal collections, respectively. In man, the cumulative fecal excretion was $0.7 \%$ of the administered radioactive ${ }^{35} \mathrm{~S}-\mathrm{CBZ}$ (Marchant, 1979 ) and $3 \%$ after administration of ${ }^{35}$ S-MMI (Alexander et al., 1969). Even lower fecal excretion of radioactivity indicated an enterohepatic circulation for MMI and/or its metabolites and indicated that the majority of the radioactivity excreted in the bile may be reabsorbed and finally excreted by the kidney. The urinary excretion rate of the administered radioactivity was 65-87\% (Balzer et al., 1975; Marchant, 1979). However, the urinary excretion of the unchanged MMI was only 5.5-8.0\% in the present study. This phenomenon may indicate that MMI is extensively metabolized.

Sitar et al. (1973) and Skellern et al. (1973) reported that the greater part of the urinary excretion after ${ }^{14} \mathrm{C}-\mathrm{MMI}$ administration to rat was found to consist of an MMI glucuronide and several other metabolites. Skellern and Steer (1981) reported six metabolites from MMI, which were not a glucuronide of $\mathrm{MMI}$, in the urine of rats receiving ${ }^{14} \mathrm{C}$-MMI intraperitoneally. In man, few urinary metabolites have been further characterized and it is not known whether the urinary metabolites have antithyroid activity or not.

After intravenous administration of the drug to normal subjects and hyperthyroid patients, the serum concentration-time prfiles could be described with a two-compartment model. The results in the present study are compatible with the assumption that hyperthyroidism does not affect the pharmacokinetics of MMI, and that interindividual variation was observed in the time taken to reach the peak concentration. 


\section{Acknowledgements}

We are grateful to Prof. H. Mashiba, The First Department of Internal Medicine, Tottori University School of Medicine, for criticism and encouragement.

\section{References}

Alexander, W. D., V. Evans, A. McAuley, T. F. Gallagher and J. Londono (1969). Metabolism of ${ }^{35}$ S-labelled antithyroid drugs in man. $\mathrm{Br}$. Med. J. II, 290-291.

Balzer, J., H. Lahrtz and P. A. van Zwieten (1975). Serumspiegel und Urinausscheidung von $\left({ }^{14} \mathrm{C}-\right)$ Thiamazol bei Patienten mit Schilddrusenuberfunktion. D. Med. Wochenschr. 100, 548-552.

Cooper, D. S., H. H. Bode, B. Nath, V. Saxe, F. Maloof and E. C. Ridgway (1984). Methimazole pharmacology in man: studies using a newly developed radioimmunoassay for methimazole. J. Clin. Endocrinol. Metab. 58, 473-479.

Crooks, J., A. J. Hedley, C. McNee and I. H. Stevenson (1973). Changes in drug metabolizing ability in thyroid disease. $B r . \quad J$. Pharmacol. 49, 156-157.

Hallengren, B., O. R. Nilsson, B. E. Karlberg, A. Melander, L. Tegler and E. Wahlin-Boll (1982). Influence of Hyperthyroidism on the Kinetics of Methimazole, Propranolol, Metoprolol and Atenolol. Eur. J. Clin. Pharmacol. 21, 379384.

Kampmann, J. and L. Skovsted (1974). The pharmacokinetics of propylthiouracil. Acta Pharmacol. Toxicol. (Kbh) 35, 361-369.

Kampmann, J. and L. Skovsted (1975). The kinetics of propylthiouracil in hyperthyroidism. Acta Pharmacol. Toxicol. (kbh) 37, 201-210.

Marchant, B. and W. D. Alexander (1972). The thyroid accumulation, oxidation and metabolic fate of ${ }^{35} \mathrm{~S}$-methimazole in the rat. Endocrinology 91, 747-756.

Marchant, B. (1979). The metabolism of ${ }^{35} \mathrm{~S}-$ labelled antithyroid drugs $(\mathrm{Ph}$. D. Thesis, University of Glasgow) cited in Hershman and Bray (Eds) The Thyroid. (Pergamon, Oxford.)

Melander, A., B. Hallengren, S. RosendalHelgesen, A. K. Sjoberg and E. Wahlin-Boll (1980). Comparative in-vitro effects and in-vivo kinetics of antithyroid drugs. Eur. J. Clin. Pharmacol. 17, 295-299.

Papapetrou, P. D., B. Marchant, H. Gavras and W. D. Alexander (1972). Biliary excretion of ${ }^{35}$ S-labeled propylthiouracil, methimazole and carbimazole in untreated and pentobarbitone pretreated rats. Biochemical Pharmacology 21, 363-377.

Pittman, J. A., R. J. Beschi and T. C. Smitherman (1971). Methimazole: its absorption and excretion in man and tissue distribution in rats. J. Clin. Endocrinol. Metab. 33, 182-185.

Shimmins, J., F. C. Gillespie, J. S. Ors, D. A. Smith and W. D. Alexander (1969). The measurement of enteric absorption rate using a double tracer technique. Adv. Biosci. 5, 157-167.

Sitar, D. S. and D. P. Thornhill (1973). Methimazole: Absorption, metabolism and excretion in the albino rat. J. Pharmacol. Exp. Ther. 184, 432-439.

Skellern, G. G., J. B. Stenlake and W. D. Williams (1973). The absorption, distribution, excretion and metabolism of $2^{-14} \mathrm{C}$-methimazole in rat. Xenobiotica 3, 121-132.

Skellern, G. G., J. B. Stenlake, W. D. Williams and D. G. MacLarty (1974). Plasma concentrations of methimazole, a metabolite of carbimazole, in hyperthyroid patients. $B r . J$. Clin. Pharmacol. 1 265-269.

Skellern, G. G., B. I. Knight and J. B. Stenlake (1976). Improved method for the determination of methimazole in plasma by high-performance liquid chromatography. J. Chromatogr. 124, 405-410.

Skellern, G. G., B. I. Knight, C. K. L. Low, W. D. Alexander, D. G. McLarty and W. J. Kalk (1980). The pharmacokinetics of methimazole after oral administration of carbimazole and methimazole in hyperthyroid patients. $B r . J$. Clin. Pharmacol. 9, 137-143.

Skellern, G. G. and S. T. Steer (1981). The Metabolism of $\left[2{ }^{14} \mathrm{C}\right]$ methimazole in the rat. Xenobiotica 11, 627-634.

Stanley, M. and E. B. Astwood (1949). 1-methyl2-mercaptoimidazole: an antithyroid compound highly active in man. Endocrinology 44, 588589.

Tatsuhara, T., F. Tabuchi, M. Unate, Y. Okamura, C. Shigemasa, K. Abe and H. Mashiba (1985). Determination of thiamazole in serum by high-performance liquid chromatography with eletrochemical detection. J. Chromatogr. 339, 
149-156.

Vesell, E. S., J. R. Shapiro, G. T. Passananti, H. Jorgensen and C. A. Shively (1975). Altered plasma half-lives of antipyrine, propythiouracil and methimazole in thyroid dysfunction. Clin. Pharmacol. Ther. 17, 48-56. 